\title{
Effect of Derris scandens extract on a human hepatocellular carcinoma cell line
}

\author{
DUANGHATHAI KULJITTICHANOK ${ }^{1}$, PENCHATR DISKUL-NA-AYUDTHAYA ${ }^{2}$, \\ CHURAT WEERAPHAN $^{2}$, DARANEE CHOKCHAICHAMNANKIT ${ }^{2}$, KHAJEELAK CHIABLAEM ${ }^{2}$, \\ KRIENGSAK LIRDPRAPAMONGKOL ${ }^{2}$, JISNUSON SVASTI ${ }^{1,2}$ and CHANTRAGAN SRISOMSAP ${ }^{2}$ \\ ${ }^{1}$ Applied Biological Sciences Program, Chulabhorn Graduate Institute; \\ ${ }^{2}$ Laboratory of Biochemistry, Chulabhorn Research Institute, Bangkok 10210, Thailand
}

Received November 7, 2016; Accepted November 2, 2017

DOI: $10.3892 / \mathrm{ol} .2018 .8824$

\begin{abstract}
The incidence rate of hepatocellular carcinoma (HCC) remains high in numerous countries, including Thailand. There are numerous different lines of HCC treatment; however, various side effects and the resistance of cancer cells during treatment remain issues. At present, traditionally used herb plants have been widely used as alternatives to cancer therapy. Derris scandens is a Thai traditional herb which is commonly found in Thailand and widely used as a traditional medicine for numerous different diseases. The cytotoxicity of D. scandens ethanolic extract on a HCC cell line (HCC-S102) was determined using an MTT assay. Following treatment with $D$. scandens ethanolic extract, the induction of apoptosis was determined by Annexin V and dead cell assays, and then confirmed by the upregulation of cleaved poly(ADP-ribose) polymerase. Furthermore, a proteomic approach was used in order to study protein alteration upon treatment with $D$. scandens ethanolic extract coupled with liquid chromatography-tandem mass spectrometry analysis for protein identification. The results suggested that $D$. scandens ethanolic extract resulted in cytotoxicity against HCC-S102 cells, as the half-maximal inhibitory concentration values were $36.0 \pm 1.0,29.6 \pm 0.6$, and $22.6 \pm 1.5 \mu \mathrm{g} / \mathrm{ml}$ at 24,48 and $72 \mathrm{~h}$, respectively. Apoptotic cells were induced following treatment with D. scandens. The comparative proteomic profiles of $D$. scandens ethanolic extract-treated and untreated cells revealed various protein targets for anticancer activity including heterogeneous nuclear ribonucleoprotein (hnRNP) K, hnRNP A2/B1, stomatin-like 2 and GAPDH. In the present study, the anticancer activity of $D$. scandens ethanolic extract was demonstrated to affect the cell proliferation
\end{abstract}

Correspondence to: Dr Chantragan Srisomsap, Laboratory of Biochemistry, Chulabhorn Research Institute, 54 Kamphaeng Phet 6, Talat Bang Khen, Bangkok 10210, Thailand

E-mail: chantragan@cri.or.th

Key words: hepatocellular carcinoma, Derris scandens, hepatocellular carcinoma cell line HCC-S102, apoptosis, proteomics of HCC-S102 via an apoptotic pathway. The alteration in these proteins provides a better understanding of the mechanism of action of D. scandens, which may be a promising anticancer agent for the treatment of patients with HCC in the future.

\section{Introduction}

Hepatocellular carcinoma (HCC), a primary liver cancer, is one of the most prevalent causes of cancer-associated mortality globally and originates from hepatocyte cells in the liver (1). Various risk factors, including chronic viral infection (including with hepatitis $\mathrm{B}$ and $\mathrm{C}$ viruses), aflatoxin exposure, alcohol ingestion and iron overload, contribute to the development of HCC (2). The incidence rate of HCC is increasing in numerous Asian countries, including Thailand (1). A majority of patients with HCC have a poor prognosis due to the first detection of disease at an advanced stage. Numerous different therapies have been devised in order to improve the prognosis and long-term survival of patients; however, limitations remain, including severe side effects such as fatigue, pain, diarrhea, nausea, vomiting, hair loss and the resistance of cancer cells to treatment (3). At present, there is a great deal of interest in traditional plant medicines, which may be used for cancer therapy or in combination with other cancer treatments.

Derris scandens, locally known as 'Thao-wan-Priang' in Thailand, belongs to the family of Leguminosae or Fabaceae. It is well-known as an Asian medicinal plant, which grows as a woody vine throughout Southeast Asia, including in Thailand. Dried stems of D. scandens have been used as an expectorant, antitussive, diuretic and anti-dysentery agent (4), and additionally for the treatment of several diseases including osteoarthritis, inflammation and muscle pains $(4,5)$. A previous study revealed that $D$. scandens ethanolic extract has potential anti-metastatic activity in cholangiocarcinoma and hepatoma cell lines equal to paclitaxel (Taxol; $10^{-9} \mathrm{M}$ ), which was used as positive control (6). Furthermore, extracts from $D$. scandens have been revealed to exert anti-proliferative effects against colon cancer by upregulating B-cell lymphoma 2-associated $\mathrm{X}$ protein (Bax), which is pro-apoptotic, and downregulating B-cell lymphoma 2 (Bcl-2) anti-apoptotic proteins (7).

Proteomic analysis is used extensively in the field of cancer research. The main principle of this technique is to separate 
proteins in two dimensions according to their isoelectric point and molecular mass. Mass spectrometry is used for protein identification following two-dimensional (2D) electrophoresis (8). These processes of proteomic analysis have been used as crucial tools in order to comprehensively monitor, identify and characterize the variations of proteins for numerous different diseases $(9,10)$. Thus, proteomic analysis is a useful tool to examine and identify the changes in protein expression in a HCC cell line in response to traditional plant treatment.

In the present study, the cytotoxicity of D. scandens ethanolic extract on a human HCC cell line, HCC-S102, was examined. Induction of cytotoxicity via apoptosis was additionally studied. As the mechanisms underlying the anti-proliferative properties of $D$. scandens on this cell line are yet to be reported, 2D electrophoresis was performed to identify protein alterations which will improve understanding of the mode of action.

\section{Materials and methods}

Plant preparation. D. scandens was purchased from a Thai medicinal herb shop in Bangkok, Thailand. Stem parts were selected and prepared using ethanol extraction. Briefly, the stem parts of dry plants were chopped and ground into small pieces. Dried ground plant materials $(50 \mathrm{~g})$ were percolated with absolute ethanol and then shaken with an orbital shaker at $60 \mathrm{rev} / \mathrm{min}$ for $22 \mathrm{~h}$ at room temperature. The plant materials in absolute ethanol solution were then filtered using Whatman filter paper no. 4 (Hyclone; GE Healthcare Life Sciences, Logan, UT, USA), followed by drying under decreased pressure to yield $62.93 \mathrm{mg}$. Ethanolic plant extracts were dissolved in dimethylsulfoxide (DMSO) at $200 \mathrm{mg} / \mathrm{ml}$ and stored as a stock solution at $-20^{\circ} \mathrm{C}$.

Cell culture. The HCC-S102 cell line, established from a Thai patient (11), was kindly provided by Dr Sumalee Tungpradabkul (Department of Biochemistry, Faculty of Science, Mahidol University, Bangkok, Thailand). Cells were maintained in RPMI-1640 medium (Gibco; Thermo Fisher Scientific, Inc., Waltham, MA, USA) supplemented with $10 \%$ fetal bovine serum (Hyclone; GE Healthcare Life Sciences), $1 \%$ penicillin/streptomycin (Gibco; Thermo Fisher Scientific, Inc.) and $125 \mathrm{ng} / \mathrm{ml}$ amphotericin B (Gibco; Thermo Fisher Scientific, Inc.). All cultures were incubated in a $\mathrm{CO}_{2}$ incubator at $37^{\circ} \mathrm{C}$ in a humidified atmosphere of $5 \% \mathrm{CO}_{2}$. Culture medium was replenished three times per week.

Cytotoxic activity. HCC-S102 cells were used to examine the cytotoxic effect of D. scandens using an MTT assay (12). Cells in culture medium were plated in 96-well plates at a density of $5 \times 10^{3}$ cells/well and incubated at $37^{\circ} \mathrm{C}$ overnight. The cells were then treated with various concentrations of $D$. scandens ethanolic extract $(0-50 \mu \mathrm{g} / \mathrm{ml})$ for 24,48 and $72 \mathrm{~h}$ in addition to DMSO (negative control) and doxorubicin (positive control) at various concentrations $(0-2.7 \mu \mathrm{g} / \mathrm{ml})$ for 24,48 and $72 \mathrm{~h}$. Subsequently, medium was discarded and replaced with $100 \mu \mathrm{l}$ fresh medium containing tetrazolium dye (Sigma-Aldrich; Merck KGaA, Darmstadt, Germany) solution $(0.5 \mathrm{mg} / \mathrm{ml})$. All plates were incubated for $2 \mathrm{~h}$ at $37^{\circ} \mathrm{C}$. Then, the medium was removed and formazan product was dissolved by the addition of $100 \mu \mathrm{l}$ DMSO to each well. Absorbance was measured at $550 \mathrm{~nm}$ with subtracted background at $650 \mathrm{~nm}$ using a microplate reader (Molecular Devices, LLC, Sunnyvale, CA, USA).

Protein extraction. Cells treated with 20 and $30 \mu \mathrm{g} / \mathrm{ml}$ D. scandens ethanolic extract for $72 \mathrm{~h}$ and control cells (treated with $0.5 \%$ DMSO) were separately washed with $0.25 \mathrm{M}$ sucrose to remove salt. Cells were then scraped into $450 \mu \mathrm{l}$ $0.25 \mathrm{M}$ sucrose containing cOmplete ${ }^{\mathrm{TM}}$, Mini Protease Inhibitor Cocktail Tablets (ratio of 1:10, Sigma-Aldrich; Merck $\mathrm{KGaA}$ ) and centrifuged at $778 \mathrm{xg}$ for $15 \mathrm{~min}$ at $4^{\circ} \mathrm{C}$. The pellets were resuspended in lysis buffer containing $9 \mathrm{M}$ urea, 2\% 3-[(3-cholamidopropyl)dimethylammonio]-1-propanesulfonate, $2 \%$ dithiothreitol (DTT), $2 \%$ ampholine [pH 3-10, the same range as that of the immobilized $\mathrm{pH}$ gradient (IPG) strip] and $1 \%$ protease inhibitor cocktail, followed by sonication on ice and centrifugation at $13,800 \mathrm{x}$ g for $10 \mathrm{~min}$ at $4^{\circ} \mathrm{C}$. Protein concentrations were determined using a Bradford assay (Bio-Rad Laboratories, Inc., Hercules, CA, USA) as previously described (13).

$2 D$ gel electrophoresis and image analysis. Amounts of $200 \mu \mathrm{g}$ of each sample were applied onto Immobiline ${ }^{\mathrm{TM}}$ Drystrips (7 cm, non-linear, pH 3-10 gradient; Bio-Rad Laboratories). IPG strips were incubated at room temperature overnight. First-dimension isoelectric focusing was performed at $6,500 \mathrm{~V} / \mathrm{h}, 55 \mu \mathrm{A}$ per gel strip using an Ettan IPGphor 3 (GE Healthcare, Little Chalfont, UK). For second-dimension SDS-PAGE, the IPG strips were equilibrated in an equilibration buffer at room temperature for $15 \mathrm{~min}$ for each step. Electrophoresis was performed in a SE 600 Ruby apparatus (GE Healthcare Life Sciences) at $10 \mathrm{~mA} / \mathrm{gel}$, followed by Coomassie blue R-250 staining as previously described (14). Gels were scanned using Labscan software (version 5.0; GE Healthcare Life Sciences) and analyzed using ImageMaster 2D Platinum (version 7.0; GE Healthcare Life Sciences). All experiments were performed independently in triplicate. Protein spots revealing a significant difference in volume ratio $(\mathrm{P}<0.05)$ were selected for protein identification by mass spectrometry analysis.

In-gel digestion. Protein spots were subjected to in-gel tryptic digestion as described previously (14). Briefly, the gels were cut into small pieces and destained using $0.1 \mathrm{M} \mathrm{NH}_{4} \mathrm{HCO}_{3}$ in $50 \%$ acetonitrile at $30^{\circ} \mathrm{C}$ for $20 \mathrm{~min}$, followed by reduction with $10 \mathrm{mM}$ DTT at $60^{\circ} \mathrm{C}$ for $45 \mathrm{~min}$ and alkylation with $100 \mathrm{mM}$ iodoacetamide at $25^{\circ} \mathrm{C}$ for $30 \mathrm{~min}$, respectively. Following the removal of reagents, gel pieces were completely dried and digested using $0.3 \mu \mathrm{g}$ trypsin (Promega Corporation, Madison, WI, USA) in $30 \mu \mathrm{l}$ digestion buffer at $37^{\circ} \mathrm{C}$ overnight. The digestion buffer was collected for protein identification.

Protein identification by liquid chromatography-tandem mass spectrometry ( $L C$-MS/MS). Identification of protein spots were performed by nanoflow liquid chromatography coupled with amaZon speed ion trap mass spectrometry (Bruker Corporation, Billerica, MA, USA). All trypsinized peptides were concentrated and desalted on a $75 \mu \mathrm{m}$ internal diameter x100 mm C $_{18}$ EASY-nLC ${ }^{\text {Tм }}$ column (Thermo Fisher Scientific, Inc.). Subsequently, the peptides were eluted by 
gradient separation using eluents $\mathrm{A}$ and $\mathrm{B}$, which were $0.1 \%$ formic acid in water and $0.1 \%$ formic acid in acetonitrile, respectively. In total, $6 \mu \mathrm{l}$ sample was injected into the nano-LC system and separated at a flow rate of $0.5 \mu \mathrm{l} / \mathrm{min}$ for $30 \mathrm{~min}$ using the following gradient: $0 \mathrm{~min} 95 \% \mathrm{~A}, 20 \mathrm{~min}$ $60 \% \mathrm{~A}, 20.5 \mathrm{~min} 5 \% \mathrm{~A}, 29 \mathrm{~min} 5 \% \mathrm{~A}$ and $29.5 \mathrm{~min} 95 \% \mathrm{~A}$, followed by MS/MS equipped with the CaptiveSpray ${ }^{\mathrm{TM}}$ source using $1.0 \mathrm{sec}$ automatic scan rate with $0.1 \mathrm{sec}$ interscan delay. For MS/MS analysis, parent mass peaks with a range between 50 and 3,000 m/z were selected. Collision energy was fixed at 1,300 V. MS/MS data were processed and converted into mgf files using Compass software (version 1.4; Bruker Corporation) and proteins were identified using the MASCOT search engine (www.matrixscience.com). Search parameters were set as follows: Database, Swiss-Prot and NCBInr; taxonomy, Homo sapiens; enzyme, trypsin; two missed cleavages allowed. Peptide and MS/MS fragment ion mass tolerance were set at 1.2 and $0.6 \mathrm{Da}$, respectively. Proteins with a consistent molecular mass and isoelectric point gel spot with a MASCOT score of $>25$ using a P-value of $\leq 0.05$ were considered to be positively identified.

Western blot analysis. Protein samples were extracted using radioimmunoprecipitation assay buffer that contained cOmplete $^{\mathrm{TM}}$, Mini Protease Inhibitor Cocktail Tablets. A total of $10 \mu \mathrm{M} \mathrm{NaF}$ (New England BioLabs, Inc., Ipswich, MA, USA), $1 \mathrm{mM}$ of $\mathrm{Na}_{3} \mathrm{VO}_{4}$ (Sigma-Aldrich; Merck KGaA) and $20 \mathrm{mM}$ of $\beta$-glycerophosphate (Merck KGaA) were used as phosphatase inhibitors. A total of $15 \mu \mathrm{g}$ protein was loaded into each lane and was separated by SDS-PAGE (12.5\% gel) and electrophoretically transferred onto polyvinylidene difluoride membranes (EMD Millipore, Billerica, MA, USA). The membranes were blocked with $3 \%$ bovine serum albumin for $1 \mathrm{~h}$ at room temperature and subsequently incubated at $4^{\circ} \mathrm{C}$ overnight with primary antibodies as follows: Rabbit polyclonal anti-poly(ADP-ribose) polymerase (PARP; 1:1,000; cat. no. 9542; Cell Signaling Technology, Inc., Danvers, MA, USA), mouse monoclonal anti- $\alpha$-tubulin (1:3,000; cat. no. 3873; Cell Signaling Technology, Inc.), rabbit polyclonal anti-heterogeneous ribonucleoprotein K (hnRNP K, 1:1,000; cat. no. 4675; Cell Signaling Technology), rabbit monoclonal anti-glyceraldehyde-3-phosphate dehydrogenase (GAPDH; 1:1,000; cat. no. ab75834; Abcam, Cambridge, UK), mouse monoclonal anti-hnRNP A2/B1 (1:1,500; cat. no. ab6102; Abcam), rabbit polyclonal anti-peroxiredoxin-4 (Prx4; 1:10,000; cat. no. ab15574; Abcam), rabbit monoclonal anti-oxygen-regulated protein 150 (ORP150, also known as HYOU1 or hypoxia-upregulated protein 1; 1:1,000; cat. no. ab134944; Abcam) and rabbit monoclonal anti-stomatin-like protein 2 (STOML2; 1:2,000; cat. no. ab191884; Abcam). The membranes were then washed 3 times with Tris-buffered saline with $0.1 \%$ Tween 20 and was incubated with a horseradish peroxidase (HRP)-conjugated polyclonal rabbit anti-mouse immunoglobulin (cat no. P0260; Dako; Agilent Technologies, Inc., Santa Clara, CA, USA) or polyclonal swine anti-rabbit immunoglobulin (cat no. P0217; Dako; Agilent Technologies, Inc.) (dilution, 1:2,000) at room temperature for $1 \mathrm{~h}$. Bands were detected using electrochemiluminescence reagent (GE Healthcare Life Sciences) and images were captured using the ImageQuant ${ }^{\mathrm{TM}}$ LAS 4000 digital imaging system (GE Healthcare Life Sciences).
Annexin $V$ and dead cell assay (flow cytometry). A total of $2 \times 10^{5}$ cells $(2 \mathrm{ml} /$ well $)$ was seeded in 6 -well plates at $37^{\circ} \mathrm{C}$ overnight. The control condition group contained $0.5 \%$ DMSO as a vehicle control. For treated cells, cells were treated with D. scandens ethanolic extract at various concentrations (20 and $30 \mu \mathrm{g} / \mathrm{ml}$ ) and further incubated at $37^{\circ} \mathrm{C}$ in a humidified atmosphere of $5 \% \mathrm{CO}_{2}$ for 24, 48 and $72 \mathrm{~h}$. Following incubation, cells were trypsinized and resuspended at $1 \times 10^{6}$ cells $/ \mathrm{ml}$ prior to staining with a 1:1 ratio of Muse ${ }^{\circledR}$ Annexin V and Dead Cell Assay kit (EMD Millipore, Billerica, MA, USA) at room temperature in the dark for $20 \mathrm{~min}$. Apoptotic analysis was performed using Muse ${ }^{\mathrm{TM}}$ Cell Analyzer (EMD Millipore), with Muse ${ }^{\mathrm{TM}}$ Analysis Software version 1.3.0.0.

Statistical analysis. All data are presented as the mean \pm standard deviation. Statistical analysis was performed by two-way analysis of variance with Tukey's Honest Significant Difference post-hoc analysis), using GraphPad Prism (version 7; GraphPad Software, Inc., La Jolla, CA, USA). $\mathrm{P}<0.05$ was considered to indicate a statistically significant difference.

\section{Results}

Cytotoxic activity of D. scandens ethanolic extract on HCC-S102 cells. To estimate the cytotoxic effect of D. scandens ethanolic extract on HCC-S102 cells, an MTT assay was performed. Half-maximal inhibitory concentration $\left(\mathrm{IC}_{50}\right)$ values were calculated, and the $\mathrm{IC}_{50}$ values were $36.0 \pm 1.0,29.6 \pm 0.6$, and $22.6 \pm 1.5 \mu \mathrm{g} / \mathrm{ml}$ at 24,48 and $72 \mathrm{~h}$, respectively (Fig. 1A). Additionally, doxorubicin was used as a positive control, and the $\mathrm{IC}_{50}$ values for the doxorubicin-treated cells were $1.1 \pm 0.03,0.6 \pm 0.01$ and $0.3 \pm 0.02 \mu \mathrm{g} / \mathrm{ml}$ at 24,48 and $72 \mathrm{~h}$, respectively (Fig. 1B).

These results reveal that $D$. scandens ethanolic extract exerts a cytotoxic effect on HCC-S102 cells in dose- and time-dependent manner compared with the control. On the basis of the inhibitory concentration of $D$. scandens ethanolic extract, the $\mathrm{IC}_{50}$ and $\mathrm{IC}_{80}$ were 20 and $30 \mu \mathrm{g} / \mathrm{ml}$, respectively, and so these doses were selected for further studies.

Detection of apoptosis of HCC-S102 cells induced by D. scandens ethanolic extract. The apoptosis-inducing effect of D. scandens ethanolic extract on HCC-S102 cells was quantified using Annexin V and dead cell assays. HCC-S102 cells were exposed to $D$. scandens ethanolic extract at concentrations of 20 and $30 \mu \mathrm{g} / \mathrm{ml}$ for 24, 48 and $72 \mathrm{~h}$. Following treatment, a gradual increase in Annexin V-positive-staining was detected in cells treated with 20 and $30 \mu \mathrm{g} / \mathrm{ml} \mathrm{D.} \mathrm{scan-}$ dens ethanolic extract compared with the control (Fig. 2A).

The proportions of total apoptotic cells demonstrated that the treatment of D. scandens ethanolic extract on HCC-S102 induced apoptosis in a dose- and time-dependent manner. Thus, total apoptotic cells were significantly increased $(\mathrm{P}<0.01)$ in cell groups treated with 20 and $30 \mu \mathrm{g} / \mathrm{ml} \mathrm{D.} \mathrm{scandens}$ ethanolic extract for 48 and $72 \mathrm{~h}$ compared with the control, and significantly increased $(\mathrm{P}<0.01)$ in the group treated with $30 \mu \mathrm{g} / \mathrm{ml}$ D. scandens ethanolic extract for $24 \mathrm{~h}$ compared with the control (Fig. 2B).

To confirm whether $D$. scandens ethanolic extract was associated with an induction of apoptosis in HCC-S102 cells, 

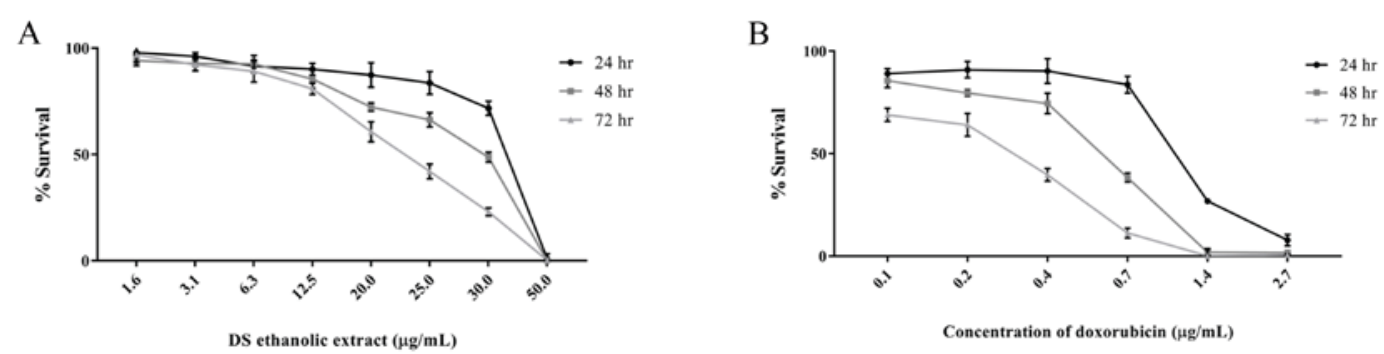

Figure 1. Cytotoxic effect of D. scandens ethanolic extract and doxorubicin on the HCC-S102 cell line. The cells were exposed to (A) D. scandens ethanolic extract or (B) doxorubicin (positive control) at the indicated dosages for 24, 48 and $72 \mathrm{~h}$, and cell viability was determined using an MTT assay. Results are expressed as the mean \pm standard deviation of three independent experiments. DS, Derris scandens.

the expression levels of cleaved PARP were determined using western blot analysis. The results revealed that treatment of HCC-S102 cells with D. scandens ethanolic extract increased the band intensity of cleaved PARP, particularly at $30 \mu \mathrm{g} / \mathrm{ml}$ (at $89 \mathrm{kDa}$; Fig. 3A). Therefore, $30 \mu \mathrm{g} / \mathrm{ml}$ D. scandens ethanolic extract resulted in significantly $(\mathrm{P}<0.01)$ increased expression levels of cleaved PARP after 24, 48, and $72 \mathrm{~h}$ of treatment (Fig. 3B). An increase in cleaved PARP expression levels confirmed the hypothesis that $D$. scandens ethanolic extract induced the death of HCC-S102 cells via the apoptotic pathway.

Effects of D. scandens ethanolic extract treatment by proteomic analysis. In order to identify any differences in protein expression, proteins were extracted from HCC-S102 cells treated with 20 and $30 \mu \mathrm{g} / \mathrm{ml} D$. scandens ethanolic extract for $72 \mathrm{~h}$. The 2D patterns of control and D. scandens ethanolic extract-treated cells (Fig. 4A-C) were then analyzed using ImageMaster 2D Platinum program. As a result, 466 protein spots were detected in D. scandens ethanolic extract-treated (either 20 or $30 \mu \mathrm{g} / \mathrm{ml}$ ) cells and, the majority of proteins were revealed to have statistically significant differences in their expression levels $>1.5$-fold change $(\mathrm{P}<0.05$; data not shown), compared with the equivalent spots in control cells. Among these, 18 protein spots that were identified to have significantly different expression levels were selected for further analysis by LC-MS/MS and subsequently identified using the MASCOT search engine and SwissProt database.

In total, 18 proteins were identified, as presented in Table I. In total, 6 upregulated proteins and 12 downregulated proteins were identified in $D$. scandens ethanolic extract-treated (20 and $30 \mu \mathrm{g} / \mathrm{ml}$ ) HCC-S102 cells compared with the control. The upregulated proteins included endoplasmin (Hsp90B1), heat-shock cognate $71 \mathrm{kDa}$ protein (Hsc70), cytoplasmic dynein 1 intermediate chain 2 (DC1I2), UDP-N-acetylhexosamine pyrophosphorylase-like protein 1, ORP150 and type I cytoskeletal keratin 9.

Downregulated proteins included chromobox protein homolog 3 (CBX3), 60S acidic ribosomal protein $\mathrm{P} 0$, filamentous actin-capping protein subunit $\alpha-1$, retinal dehydrogenase 1 (RALDH1), aldo-keto reductase family 1 member $\mathrm{C} 1$ (AKR1C1), GAPDH, neurocalcin- $\delta$, cytochrome $b c_{1}$ complex subunit 1 (UQCRC1), glutaredoxin-3 (TXNL2), peroxiredoxin-4 (Prx4), hnRNP K, hnRNP A2/B1 and STOML2.

Validation of differential 2D electrophoresis protein expression levels by western blot analysis. To validate the difference of the expression levels of the proteins of interest, which have been reported to be involved in the survival of cancer cells (15-20), western blot analysis was used to confirm the differences of protein expression levels between $D$. scandens ethanolic extract-treated cells and untreated cells. ORP150 was revealed to be significantly increased $(\mathrm{P}<0.0001)$ in D. scandens ethanolic extract-treated cells compared with the control, which is consistent with the $2 \mathrm{D}$ electrophoresis result. Similarly, STOML2 was revealed to be significantly decreased in $20 \mu \mathrm{g} / \mathrm{ml}$ D. scandens ethanolic extract-treated cells $(\mathrm{P}<0.05)$, and Prx4, STOML2, hnRNP K and hnRNP A2/B1 were all significantly decreased in $30 \mu \mathrm{g} / \mathrm{ml}$ treated cells $(\mathrm{P}<0.05)$ compared with the control (Fig. 5A and B).

\section{Discussion}

Cancer is a major health problem, thus developments of novel cancer treatments are required. It has been reported that certain plant extracts have the potential to be used as anticancer drugs by enhancing the immune system, inducing cell differentiation, inhibiting telomerase activities and inducing apoptosis in vitro and in vivo (21). In Thailand, certain herbs have been widely used for a long time. However, the underlying molecular mechanisms of action of the Thai herbs (e.g., Bridelia ovata Decne or Dioscorea membranacea Pierre) for cancer treatment are still being investigated. In the present study, the effect of $D$. scandens stem ethanolic extract on the HCC-S102 cell line were determined.

According to the criteria of cytotoxicity activity for crude extracts from the American National Cancer Institute (NCI), a concentration of plant extract $\leq 30 \mu \mathrm{g} / \mathrm{ml}$ with an incubation time of between 48 and $72 \mathrm{~h}$ is considered to be 'active' due to the calculation of the $\mathrm{IC}_{50}$ value (22). The D. scandens ethanolic extract was investigated for cytotoxic activity in HCC-S102 cells. The $\mathrm{IC}_{50}$ value following treatment for $72 \mathrm{~h}$ was $22.6 \pm 1.5 \mu \mathrm{g} / \mathrm{ml}$, which is of potential interest in terms of the NCI criteria. One previous study indicated that ethanolic crude extract of $D$. scandens exhibited potent cytotoxic activity against the lung adenocarcinoma cell line (CORL-23) with an $\mathrm{IC}_{50}$ value of $21.04 \pm 0.57 \mu \mathrm{g} / \mathrm{ml}$ following treatment for $72 \mathrm{~h}$ (23). Furthermore, the cytotoxic activity of $D$. scandens ethanolic extract has been investigated using other lung cancer cell lines (namely, A549 and NCI-H226) compared with lung normal cells, with the results indicating that $D$. scandens ethanolic extract exhibited an increased cytotoxic activity in lung cancer cell lines compared with normal lung cells ( $\left.\mathrm{IC}_{50}, 65.04 \mu \mathrm{g} / \mathrm{ml}\right)(24)$. 
A
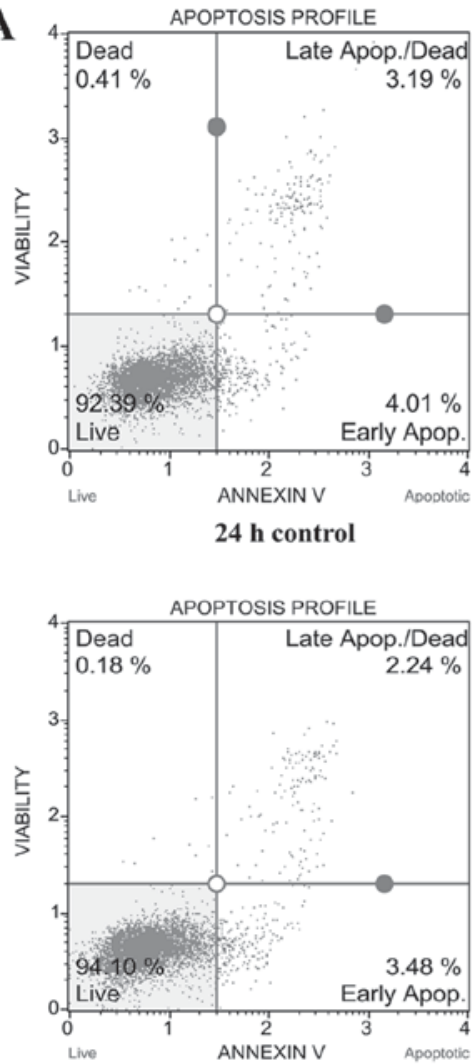

48 h control

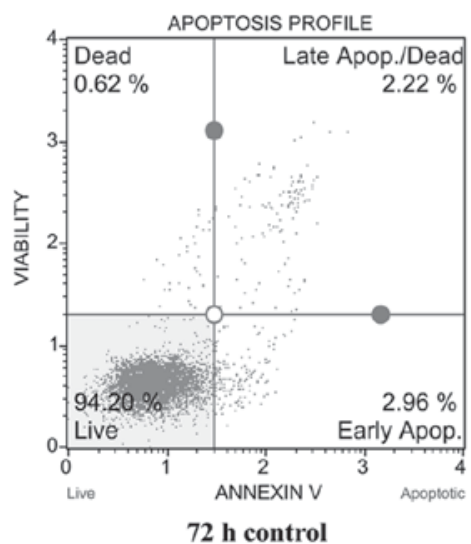

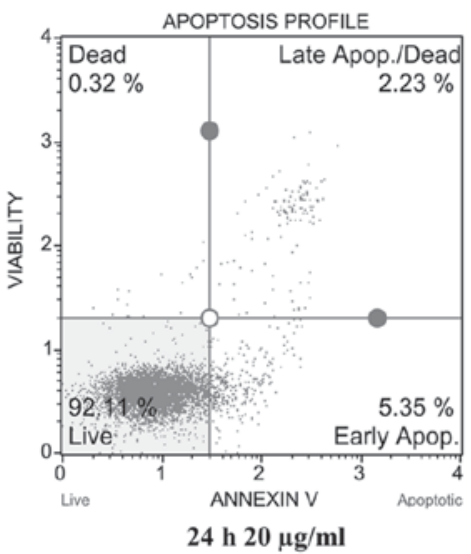

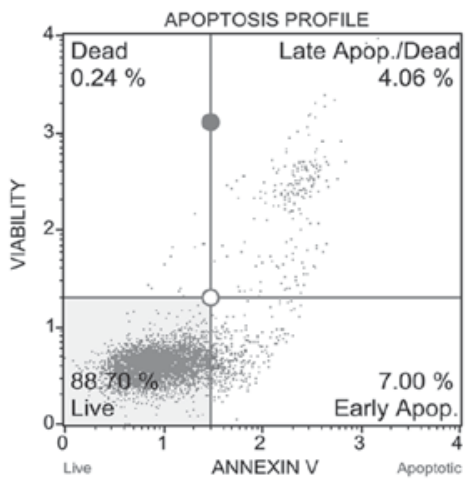

48 h $20 \mu \mathrm{g} / \mathrm{ml}$

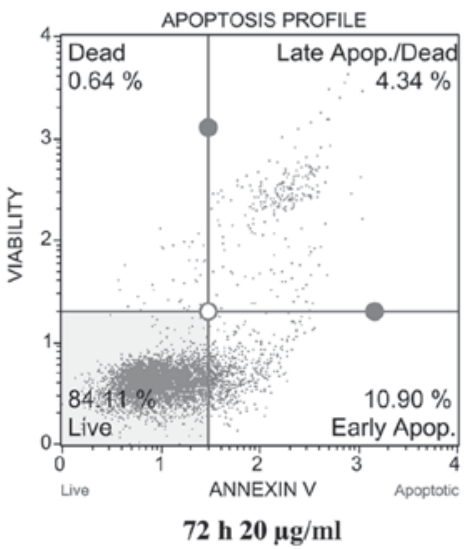

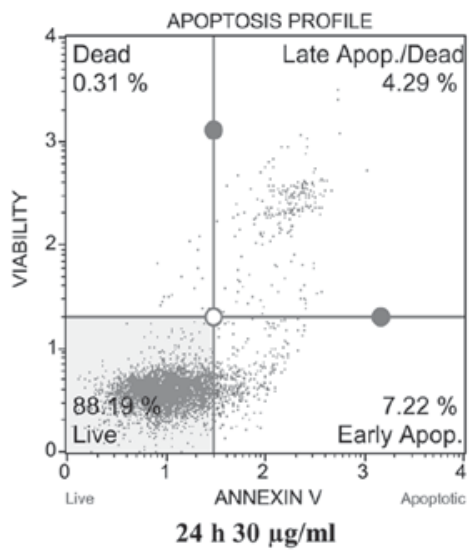

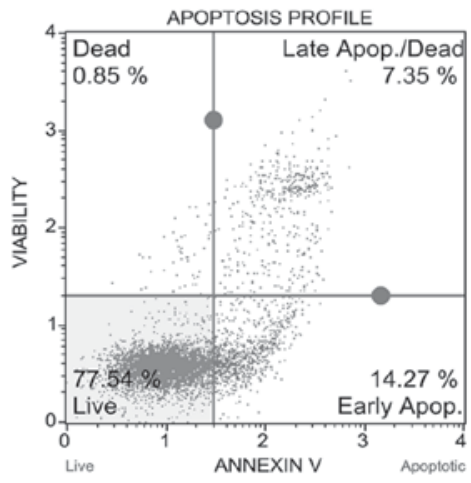

$48 \mathrm{~h} 30 \mu \mathrm{g} / \mathrm{m}$

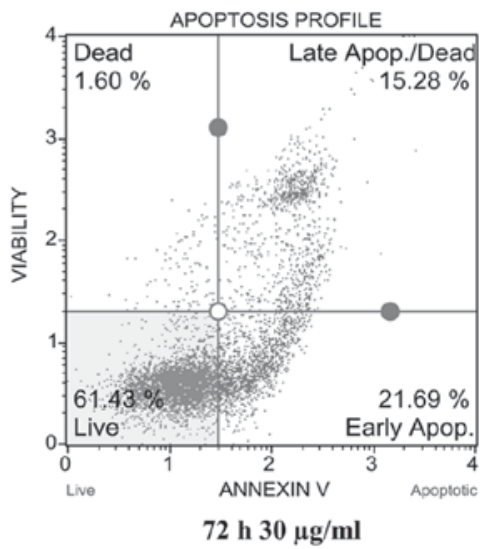

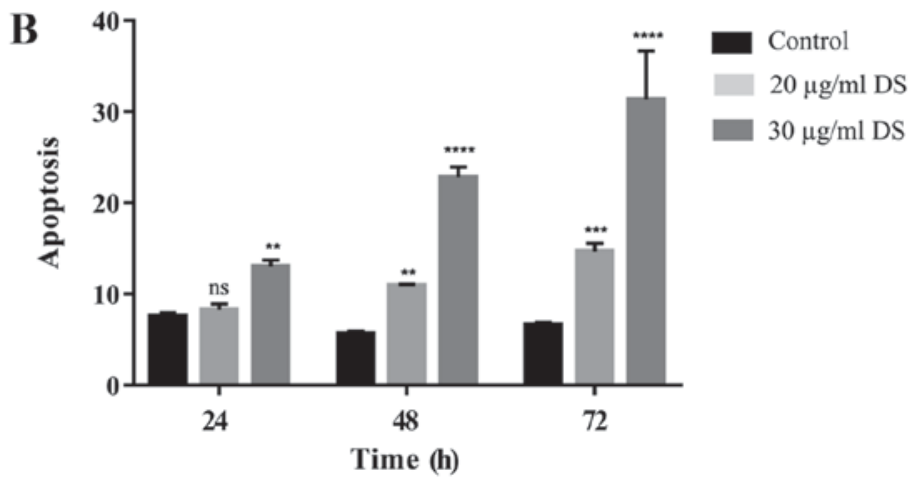

Figure 2. Effect of D. scandens ethanolic extract on the apoptosis of the HCC-S102 cell line. (A) Flow cytometry with Muse analysis demonstrated that the proportion of total apoptotic cells increased in the HCC-S102 cell line with increasing doses and durations of treatment with $D$. scandens ethanolic extract. (B) Percentage of total apoptotic cells observed following treatment with 20 and $30 \mu \mathrm{g} / \mathrm{ml}$ D. scandens ethanolic extract for 24,48 and $72 \mathrm{~h}$ compared with the control. Results are expressed as the mean \pm standard deviation. ${ }^{* *} \mathrm{P}<0.01$ and ${ }^{* * * *} \mathrm{P}<0.001$ vs. the control. NS, non-significant; DS, Derris scandens ethanolic extract. 

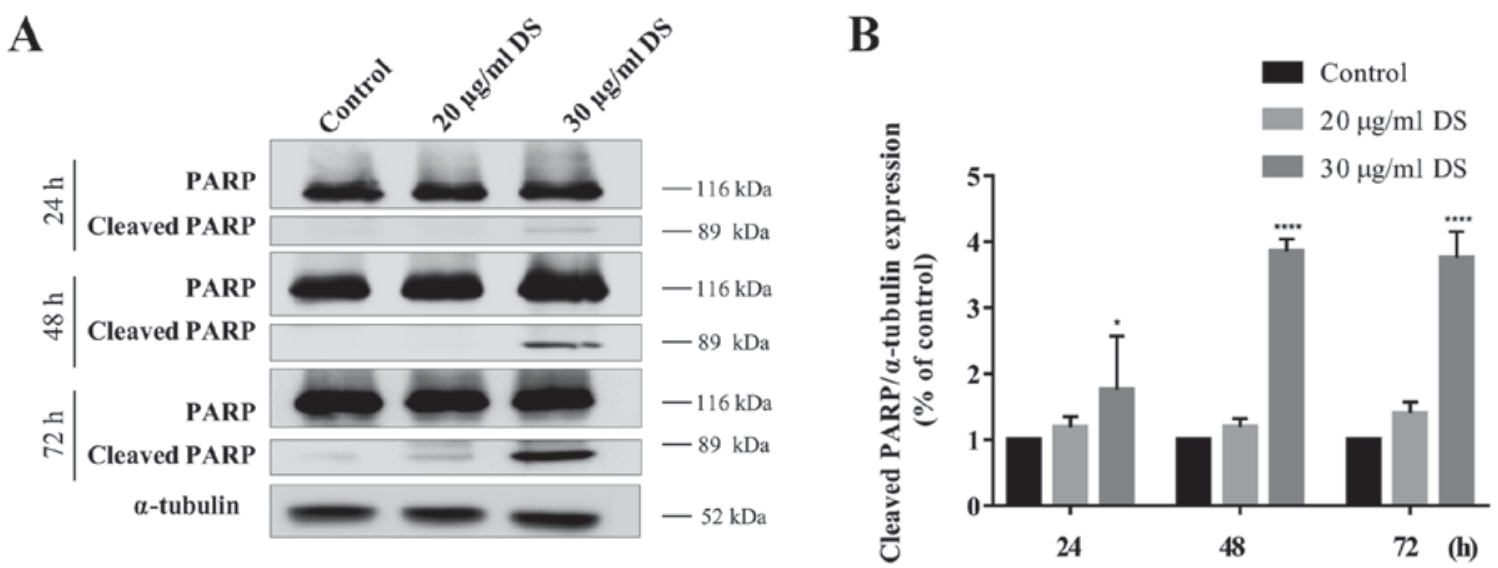

Figure 3. Effect of D. scandens ethanolic extract on the expression levels of cleaved PARP in the HCC-S102 cell line. (A) Western blot analysis results revealed an upregulation of the expression of cleaved PARP ( $89 \mathrm{kDa}$ ) following treatment with D. scandens ethanolic extract for 24, 48 and $72 \mathrm{~h}$. (B) Fold changes of cleaved PARP expression levels compared with the control at different treatment doses $(20$ and $30 \mu \mathrm{g} / \mathrm{ml})$ and times $(24,48$ and $72 \mathrm{~h})$. $\alpha$-tubulin $(52 \mathrm{kDa})$ was used as a loading control. Results are expressed as the mean \pm standard deviation. ${ }^{*} \mathrm{P}<0.05$ and ${ }^{* * *} \mathrm{P}<0.001$ vs. the control. DS, Derris scandens ethanolic extract; PARP, poly(ADP-ribose) polymerase.
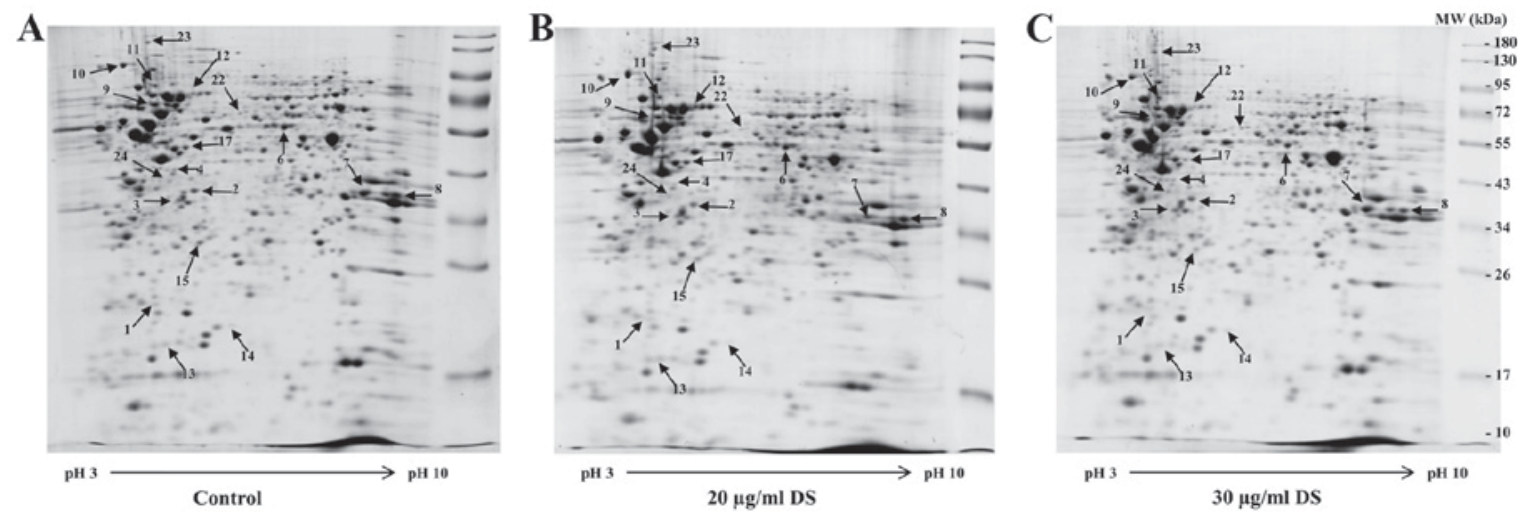

Figure 4. 2D electrophoresis map of proteins from the HCC-S102 cell line treated with D. scandens ethanolic extract. 2D electrophoresis was performed on a $\mathrm{pH}$ 3-10 non-linear immobilized pH gradient strip $(7 \mathrm{~cm})$, followed by SDS-PAGE (12.5\% gel). Proteins were isolated after exposure of the cells to (A) control and (B) 20 and (C) $30 \mu \mathrm{g} / \mathrm{ml}$ D. scandens ethanolic extract for $72 \mathrm{~h}$. The gels were stained with Coomassie blue R-250.2D, two-dimensional; DS, Derris scandens ethanolic extract; MW, molecular mass.

D. scandens ethanolic extract has been revealed to have anti-proliferative effects against colon cancer cell lines, mediating cell death through necrosis in the SW480 colon cancer cell line (7). Hematulin et al (5) reported that colon cancer cells (HT-29) treated with $D$. scandens ethanolic extract exhibited increased apoptosis induction compared with cells treated with a combination of radiation and $D$. scandens ethanolic extract. However, cell death from $D$. scandens ethanolic extract in combination with radiation was increased compared with in $D$. scandens ethanolic extract alone, suggesting that other modes of cell death were involved in colon cancer cell lines.

To determine how $D$. scandens ethanolic extract exerts cytotoxicity on the HCC-S102 cell line, a cell death mechanism, apoptosis, was studied using an Annexin V and dead cell assay, which detects the translocation of phosphatidylserine from the inner to the outer cell-surface membrane, which occurs during apoptosis. Using a double stain of Annexin V-fluorescein isothiocyanate (FITC) and 7-aminoactinomycin D (7-AAD), cells were classified as living cells or cells at early or late stages of apoptosis. HCC-S102 cells treated with D. scandens ethanolic extract were stained with Annexin V-FITC and 7-AAD, and then quantified using flow cytometric analysis. Results revealed that cell apoptosis from $D$. scandens ethanolic treatment was dose- and time-dependent. At higher doses, treated cells were killed via the apoptosis pathway following incubation with $D$. scandens extract for 48 and $72 \mathrm{~h}$.

PARP is a nuclear DNA-binding protein, which is typically cleaved by caspase- 3 during apoptosis, thus the detection of PARP cleavage is used as an indicator of apoptosis (25). The results of the present study revealed that there was a significantly increased intensity of cleaved PARP protein in treated cells at different doses and times compared with the control. This corresponds with the results of the flow cytometric experiments, and confirms that D. scandens ethanolic extract treatment induced apoptosis in HCC-S102 cells.

Proteomic analysis was used to investigate differentially expressed proteins between HCC-S102 cells treated with D. scandens ethanolic extract for $72 \mathrm{~h}$ and untreated control cells. A total of 18 significantly different protein spots were analyzed using Image Master and identified by LC-MS/MS. Cells treated with $D$. scandens extract possessed 6 proteins 


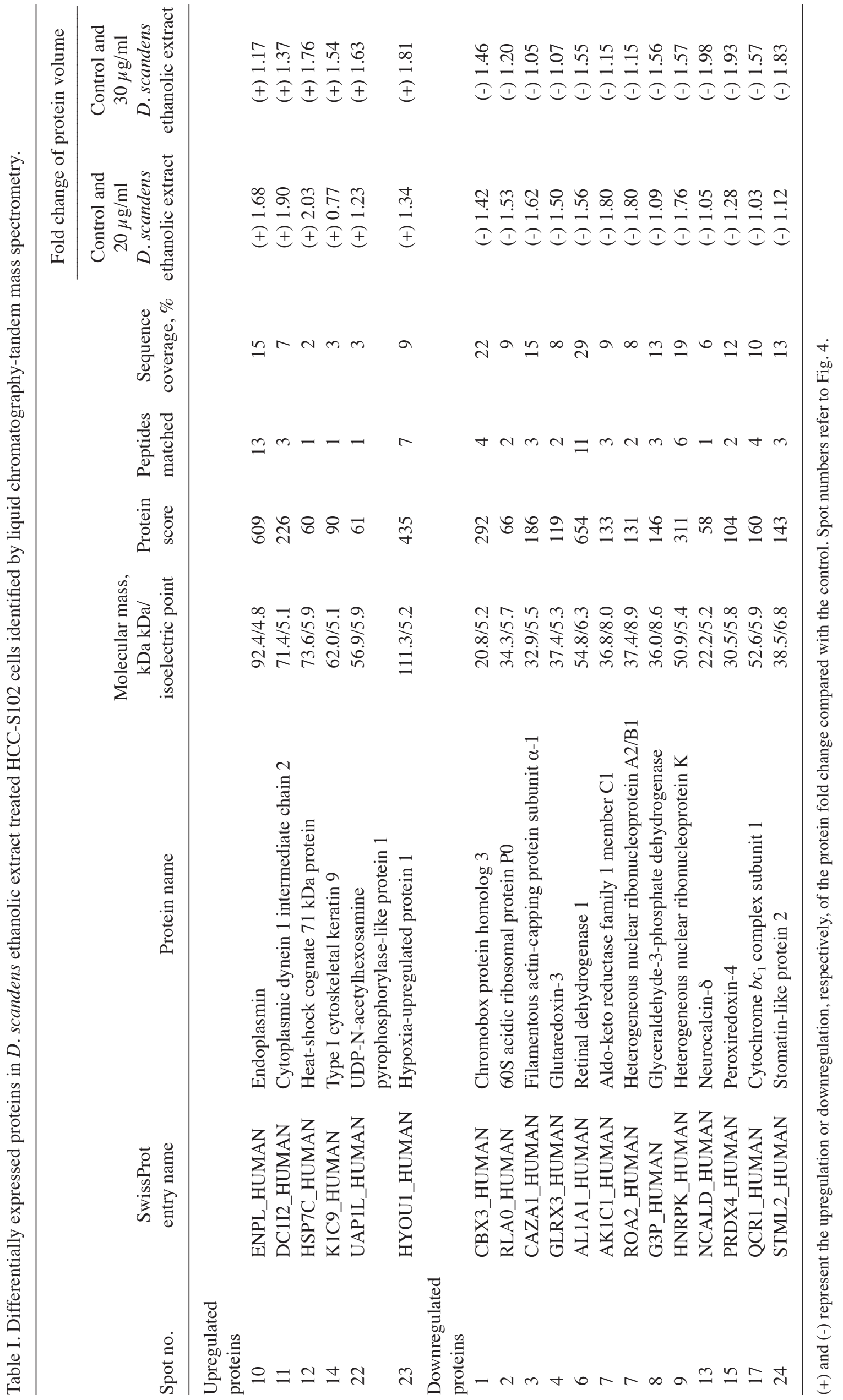


A

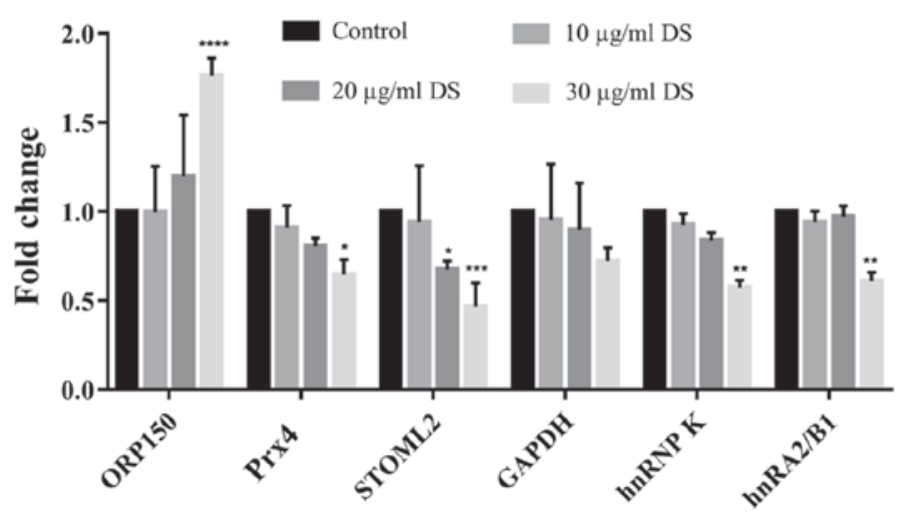

B

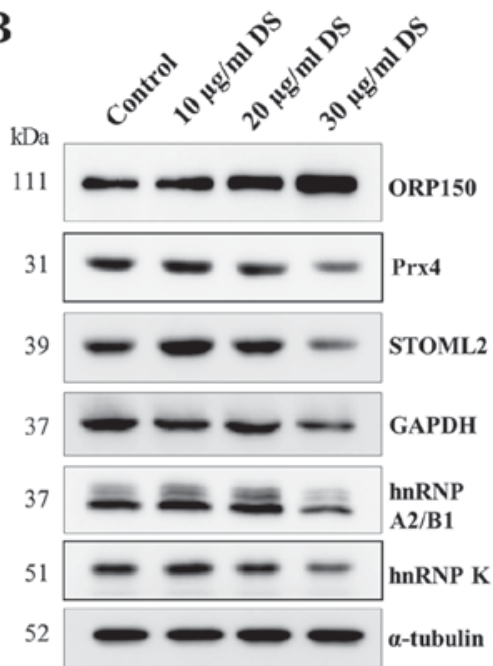

Figure 5. Verification of the expression of representative proteins from two-dimensional electrophoresis on the HCC-S102 cell line treated with $D$. scandens ethanolic extract. Cells were treated with different concentrations of $D$. scandens ethanolic extract (10, 20 and $30 \mu \mathrm{g} / \mathrm{ml})$ for $72 \mathrm{~h}$ and subjected to SDS-PAGE (12.5\% gel), followed by western blot analysis. (A) Fold change of and (B) western blot analysis results for ORP150, Prx4, GAPDH, STOML2, hnRNP A2/B1 and hnRNP K. $\alpha$-tubulin was used as loading control. Results are expressed as the mean \pm standard deviation. ${ }^{*} \mathrm{P}<0.05,{ }^{* * *} \mathrm{P}<0.01,{ }^{* * * *} \mathrm{P}<0.001$ and ${ }^{* * * *} \mathrm{P}<0.0001$ vs. the control. DS, Derris scandens ethanolic extract; ORP150, oxygen-regulated protein 150; Prx4, peroxiredoxin-4; STOML2, stomatin-like protein 2; hnRNP, heterogeneous nuclear ribonucleoprotein.

with higher expression and 13 proteins with lower expression compared with untreated controls. A majority of proteins involved in stress response including Hsp90B1, Hsc70 and ORP150 were upregulated. Downregulated proteins involved in cell metabolism included RALDH1, AKR1C, GAPDH, UQCRC1 and STOML2. In addition, TXNL2 and Prx4 which serve functions as antioxidants were downregulated. Proteins participating in transcriptional regulation including $\mathrm{CBX} 3$ and hnRNP K were downregulated, as were proteins involved in signal transduction including hnRNP A2/B1. Among these proteins, ORP150, Prx4, GAPDH, STOML2, hnRNP A2/B1 and hnRNP K proteins were selected to validate the differential expression of these proteins between treated and untreated cells using western blot analysis. In agreement with the proteomic results, western blot analysis revealed that ORP150 was upregulated whereas Prx4, GAPDH, STOML2, hnRNP A2/B1 and hnRNP K proteins were downregulated.

Prx4 is a member of the thiol-specific antioxidant group of proteins, and is normally expressed in the endoplasmic reticulum (ER) of cells (15). Its general function is to serve as an antioxidant by decreasing the production of reactive oxygen species (ROS). In addition, a previous study revealed that Prx 4 additionally participated in oxidative protein folding as a molecular chaperone in order to facilitate protein folding in the ER (26). High expression of Prx4 has been reported in numerous different tumor types, including lung cancer, colorectal cancer and high-grade glioma (primary brain malignancy) $(15,27,28)$. For example, Prx 4 is highly expressed in and associated with the development of human lung cancer, and has been suggested to be useful as a good prognostic marker of cancer progression in early-stage squamous cell carcinoma of lung cancer (15). Additionally, a previous study used immunohistochemistry and quantitative polymerase chain reaction to demonstrate that the expression of the Prx4 gene and protein were higher in colorectal cancer tissues compared with normal tissues (27). Notably, Kim et al (28) have previously revealed that Piperlongumine, a natural plant product, suppressed the expression of Prx4 and subsequently increased ROS and ER stress levels in glioma cells. Excess misfolded or unfolded proteins in ER may induce the ER stress response, which may be detected by the expression of ORP150.

ORP150 is a notable molecular chaperone in the ER, which belongs to the heat-shock protein 70 family (29). The ORP150 system is a part of the ER machinery associated with the folding and assembly of secretory and membrane proteins in the ER (16). ORP150 expression was induced by numerous stress conditions including the accumulation of protein unfolding and the depletion of glucose or oxygen (16). Under stress conditions, ORP150 may accumulate in the ER, serving a cytoprotective function for cells. The upregulation of ORP150 has been reported in numerous types of cancer including breast cancer (28), bladder cancer (30) and nasopharyngeal carcinoma (31). Prx4 downregulation concomitantly with the upregulation of ORP150 indicates an increase in ER stress and ROS levels in the HCC-S102 cell line. The evidence suggests that, together, prolonged unfolded protein accumulation and persistent ER stress in cancer cells may initiate pro-apoptotic signaling (32). Thus, it may be deduced that these consequences will occur in HCC-S102 cells when treated with D. scandens ethanolic extract.

GAPDH and STOML2 are involved in cell metabolism. GAPDH is a key regulatory enzyme of glycolysis, and serves a crucial function in several biological processes including the control of gene expression, DNA replication and repair and apoptosis (33). There is evidence that GAPDH expression is increased in various human cancer types, including ovarian, lung and colon cancer types $(17,34,35)$. Furthermore, previous studies have revealed that GAPDH knockdown by small interfering RNA (siRNA) results in a significant decrease in the proliferative, migratory and invasive abilities of lung squamous carcinoma cells in vitro (36). STOML2 is a protein on the mitochondrial inner membrane; however, 
its functions remain unknown (37). STOML2 has been implicated in serving an important function in sustaining the mitochondria membrane potential and ATP production, and additionally affects cell activity including cell motility and cell growth in tumor cells (18). Furthermore, it has been reported that the downregulation of STOML2 increases the sensitivity of cancer cells to chemotherapeutic treatments by inducing cancer cell apoptosis and cell cycle arrest (18). The results of the present study revealed the downregulation of GAPDH and STOML2, which may be one of the mechanisms of $D$. scandens ethanolic extract resulting in cytotoxicity in HCC-S102 cells.

The hnRNP family are considered to be an important factor in mRNA processing and biogenesis (38). The present study revealed a decrease in the expression levels of hnRNP $\mathrm{K}$ and hnRNP A2/B1 in the HCC-S102 cell line treated with D. scandens ethanolic extract. hnRNP $\mathrm{K}$ is a member of the hnRNP family. It exerts specific binding for the c-myc promoter and functions as a transcription factor (39). Association of hnRNP K with tumor development in various types of cancer have been reported. A previous study revealed that hnRNP K may be involved in hepatocarcinogenesis by enhancing hepatitis B and hepatitis C replication and cell proliferation (19). In lung cancer, the downregulation of hnRNP K by siRNA resulted in the inhibition of cell growth and increased apoptosis in a lung cancer cell line (A549) (40). In addition, there is evidence that hnRNP K suppresses apoptosis in HCC and nasopharyngeal carcinoma $(41,42)$.

hnRNP A2/B1 is another member of the hnRNP family that was revealed to be downregulated in the present study. hnRNP A2/B1 has several cellular functions including regulating gene expression at the transcriptional and translational level. hnRNP A2/B1 has been reported to be overexpressed in tumorigenesis, and may be a potential biomarker for early detection, particularly in lung cancer (43). To assess the risk of human liver cancer, the increased expression and cytoplasmic localization of hnRNP A2/B1 may be used as a diagnostic biomarker (20). Furthermore, the inhibition of hnRNP A2/B1 expression has been demonstrated to increase the sensitivity of cancer cells to chemotherapy, stimulate apoptosis and additionally modulate the promotion of pancreatic cancer (44). hnRNP K and hnRNP A2/B1 expression levels were decreased with the treatment with $D$. scandens ethanolic extract in the present study. Therefore, this may be one of the mechanisms involved in the cytotoxic activity against HCC-S102 cells.

In conclusion, the present study demonstrated that the effect of D. scandens ethanolic extract on HCC-S102 cell line occurs through the apoptotic pathway. The proteomic profiling of cells treated with $D$. scandens ethanolic extract identified numerous protein targets for anticancer activity including hnRNP K, hnRNP A2/B1, STOML2 and GAPDH. It may be suggested that the decrease in the survival of HCC-S102 cells by alterations in these proteins may potentiate the lethal effect of $D$. scandens-induced Prx4 downregulation and excess ER stress as indicated by OR P150 upregulation. Consequently, the present results indicate the association of the apoptosis mechanism with cell cytotoxicity upon treatment of $D$. scandens ethanolic extract. However, further studies on the function of each protein are necessary in order to elucidate the mode of action of D. scandens ethanolic extract.

\section{Acknowledgements}

The present study was supported by the Chulabhorn Graduate Institute (grant no. 10/2556) and the Chulabhorn Research Institute (grant no. BC2008-02).

\section{References}

1. Somboon K, Siramolpiwat S and Vilaichone RK: Epidemiology and survival of hepatocellular carcinoma in the central region of Thailand. Asian Pac J Cancer Prev 15: 3567-3570, 2014.

2. Mittal S and El-Serag HB: Epidemiology of HCC: Consider the population. J Clin Gastroenterol 47: S2-S6, 2013.

3. Safarzadeh E, Shotorbani SS and Baradaran B: Herbal medicine as inducers of apoptosis in cancer treatment. Adv Pharm Bull 4 (Suppl 1): S421-S427, 2014.

4. Hussain H, Al-Harrasi A, Krohn K, Kouam SF, Abbas G, Shah A Raees MA, Ullah R, Aziz S and Schulz B: Phytochemical investigation and antimicrobial activity of Derris scandens. J King Saud Univ Sci 27: 375-378, 2015.

5. Hematulin A, Ingkaninan K, Limpeanchob $\mathrm{N}$ and Sagan D: Ethanolic extract from Derris scandens Benth mediates radiosensitzation via two distinct modes of cell death in human colon cancer HT-29 cells. Asian Pac J Cancer Prev 15: 1871-1877, 2014.

6. Laupattarakasem P, Sripa B and Laupattarakasem W: Antimigration of cancer cells by Derris scandens on Cholangiocarcinoma cells. Srinagarind Med J 22: 339-345, 2010.

7. Kaewkon K, Khamprasert N and Limpeanchob N: Derris scandens benth extract induces necrosis rather than apoptosis of SW480 colon cancer cells. Thai J Pharmacol 33: 118-121, 2011.

8. Li Y, Geng X and Zhang W: Application of proteomics to the study of hepatocellular carcinoma and some related diseases. Chin Jof Clin Oncol 2: 903-906, 2005.

9. Lee SY, Kim GT, Roh SH, Song JS, Kim HJ, Hong SS, Kwon SW and Park JH: Proteomic analysis of the anti-cancer effect of 20 S-ginsenoside Rg3 in human colon cancer cell lines. Biosci Biotechnol Biochem 73: 811-816, 2009.

10. Srisomsap C, Sawangareetrakul P, Subhasitanont P, Chokchaichamnankit D, Chiablaem K, Bhudhisawasdi V, Wongkham S and Svasti J: Proteomic studies of cholangiocarcinoma and hepatocellular carcinoma cell secretomes. J Biomed Biotechnol 2010: 437143, 2010.

11. Laohathai $\mathrm{K}$ and Bhamarapravati $\mathrm{N}$ : Culturing of human hepatocellular carcinoma. A simple and reproducible method. Am J Pathol 118: 203-208, 1985.

12. Chiablaem K, Lirdprapamongkol K, Keeratichamroen S, Surarit R and Svasti J: Curcumin suppresses vasculogenic mimicry capacity of hepatocellular carcinoma cells through STAT3 and PI3K/AKT inhibition. Anticancer Res 34: 1857-1864, 2014.

13. Bradford MM: A rapid and sensitive method for the quantitation of microgram quantities of protein utilizing the principle of protein-dye binding. Anal Biochem 72: 248-254, 1976.

14. Khongmanee A, Lirdprapamongkol K, Tit-oon P, Chokchaichamnankit D, Svasti J and Srisomsap C: Proteomic analysis reveals important role of 14-3-3 $\sigma$ in anoikis resistance of cholangiocarcinoma cells. Proteomics 13: 3157-3166, 2013.

15. Hwang JA, Song JS, Yu DY, Kim HR, Park HJ, Park YS, Kim WS and Choi CM: Peroxiredoxin 4 as an independent prognostic marker for survival in patients with early-stage lung squamous cell carcinoma. Int J Clin Exp Pathol 8: 6627-6635, 2015.

16. Krętowski R, Stypułkowska A and Cechowska-Pasko M: Low-glucose medium induces ORP150 expression and exerts inhibitory effect on apoptosis and senescence of human breast MCF7 cells. Acta Biochim Pol 60: 167-173, 2013.

17. Tang Z, Yuan S, Hu Y, Zhang H, Wu W, Zeng Z, Yang J, Yun J, $\mathrm{Xu} \mathrm{R}$ and Huang P: Over-expression of GAPDH in human colorectal carcinoma as a preferred target of 3-bromopyruvate propyl ester. J Bioenerg Biomembr 44: 117-125, 2012.

18. Wang Y, Cao W, Yu Z and Liu Z: Downregulation of a mitochondria associated protein SLP-2 inhibits tumor cell motility, proliferation and enhances cell sensitivity to chemotherapeutic reagents. Cancer Biol Ther 8: 1651-1658, 2009. 
19. Hsieh TY, Matsumoto M, Chou HC, Schneider R, Hwang SB, Lee AS and Lai MM: Hepatitis $C$ virus core protein interacts with heterogeneous nuclear ribonucleoprotein K. J Biol Chem 273: 17651-17659, 1998.

20. Cui H, Wu F, Sun Y, Fan G and Wang Q: Up-regulation and subcellular localization of hnRNP A2/B1 in the development of hepatocellular carcinoma. BMC cancer 10: 356, 2010.

21. Tavakoli J, Miar S, Zadehzare MM and Akbari H: Evaluation of effectiveness of herbal medication in cancer care: A review study. Iran J Cancer Prev 5: 144-156, 2012.

22. Malek SN, Phang CW, Ibrahim H, Norhanom AW and Sim KS: Phytochemical and cytotoxic investigations of Alpinia mutica rhizomes. Molecules 16: 583-589, 2011.

23. Saetung A, Itharat A, Dechsukum C, Wattanapiromsakul C, Keawpradub $\mathrm{N}$ and Ratanasuwan P: Cytotoxic activity of Tha medicinal plants for cancer treatment. Songklanakarin J Sci Technol 27 (Suppl 2): S469-S478, 2005.

24. Prommee N, Prajuabjinda O and Itharat A: In vitro cytotoxic, antioxidant and antimicrobial activities of Derris Scandens. In: Proceedings of the First Conference on Graduate Student Network of Thailand, Pathumthani, Bangkok, 2012.

25. Li Y, Kong D, Bao B, Ahmad A and Sarkar FH: Induction of cancer cell death by isoflavone: The role of multiple signaling pathways. Nutrients 3: 877-896, 2011.

26. Zito E, Melo EP, Yang Y, Wahlander A, Neubert TA and Ron D: Oxidative protein folding by an endoplasmic reticulum-localized peroxiredoxin. Mol Cell 40: 787-797, 2010.

27. Yi N, Xiao MB, Ni WK, Jiang F, Lu CH and Ni RZ: High expression of peroxiredoxin 4 affects the survival time of colorectal cancer patients, but is not an independent unfavorable prognostic factor. Mol Clin Oncol 2: 767-772, 2014.

28. Kim TH, Song J, Kim SH, Parikh AK, Mo X, Palanichamy K, Kaur B, Yu J, Yoon SO, Nakano I and Kwon CH: Piperlongumine treatment inactivates peroxiredoxin 4 , exacerbates endoplasmic reticulum stress, and preferentially kills high-grade glioma cells. Neuro Oncol 16: 1354-1364, 2014.

29. Stojadinovic A, Hooke JA, Shriver CD, Nissan A, Kovatich AJ, Kao TC, Ponniah S, Peoples GE and Moroni M: HYOU1/Orp150 expression in breast cancer. Med Sci Monit 13: BR231-BR239, 2007.

30. Asahi H, Koshida K, Hori O, Ogawa S and Namiki M: Immunohistochemical detection of the $150-\mathrm{kDa}$ oxygen-regulated protein in bladder cancer. BJU Int 90: 462-466, 2002.

31. Zhou Y, Liao Q, Li X, Wang H, Wei F, Chen J, Yang J, Zeng Z, Guo X, Chen P, et al: HYOU1, regulated by LPLUNC1, is up-regulated in nasopharyngeal carcinoma and associated with poor prognosis. J Cancer 7: 367-376, 2016.

32. Schönthal AH: Pharmacological targeting of endoplasmic reticulum stress signaling in cancer. Biochem Pharmacol 85: 653-666, 2013
33. Zhang JY, Zhang F, Hong CQ, Giuliano AE, Cui XJ, Zhou GJ, Zhang GJ and Cui YK: Critical protein GAPDH and its regulatory mechanisms in cancer cells. Cancer Biol Med 12: 10-22, 2015.

34. Hjerpe E, Egyhazi Brage S, Carlson J, Frostvik Stolt M, Schedvins K, Johansson H, Shoshan M and Avall-Lundqvist E: Metabolic markers GAPDH, PKM2, ATP5B and BEC-index in advanced serous ovarian cancer. BMC Clin Pathol 13: 30, 2013.

35. Puzone R, Savarino G, Salvi S, Dal Bello MG, Barletta G, Genova C, Rijavec E, Sini C, Esposito AI, Ratto GB, et al: Glyceraldehyde-3-phosphate dehydrogenase gene over expression correlates with poor prognosis in non small cell lung cancer patients. Mol Cancer 12: 97, 2013.

36. Hao L, Zhou X, Liu S, Sun M, Song Y, Du S, Sun B, Guo C, Gong L, Hu J, et al: Elevated GAPDH expression is associated with the proliferation and invasion of lung and esophageal squamous cell carcinomas. Proteomics 15: 3087-3100, 2015.

37. Xiao B, Xie Z, Guo L, Wu J and Zhang H: Stomatin-like protein 2 expression is associated with clinical survival in patients with cervical cancer. Int J Clin Exp Pathol 8: 1804-1809, 2015.

38. Geuens T, Bouhy D and Timmerman V: The hnRNP family: Insights into their role in health and disease. Hum Genet 135: 851-867, 2016.

39. Lu J and Gao FH: Role and molecular mechanism of heterogeneous nuclear ribonucleoprotein $\mathrm{K}$ in tumor development and progression. Biomed Rep 4: 657-663, 2016.

40. Tang F, Li W, Chen Y, Wang D, Han J and Liu D: Downregulation of hnRNP K by RNAi inhibits growth of human lung carcinoma cells. Oncol Lett 7: 1073-1077, 2014

41. Xiao Z, Ko HL, Goh EH, Wang B and Ren EC: hnRNP K suppresses apoptosis independent of p53 status by maintaining high levels of endogenous caspase inhibitors. Carcinogenesis 34: 1458-1467, 2013

42. Chen LC, Chung I, Hsueh C, Tsang NM, Chi LM, Liang Y, Chen CC, Wang LJ and Chang YS: The antiapoptotic protein, FLIP, is regulated by heterogeneous nuclear ribonucleoprotein $\mathrm{K}$ and correlates with poor overall survival of nasopharyngeal carcinoma patients. Cell Death Differ 17: 1463-1473, 2010.

43. Qu XH, Liu JL, Zhong XW, Li X and Zhang QG: Insights into the roles of hnRNP A2/B1 and AXL in non-small cell lung cancer. Oncol Lett 10: 1677-1685, 2015.

44. Gu WJ and Liu HL: Induction of pancreatic cancer cell apoptosis, invasion, migration, and enhancement of chemotherapy sensitivity of gemcitabine, 5-FU, and oxaliplatin by hnRNP A2/B1 siRNA. Anticancer Drugs 24: 566-576, 2013. 